\title{
ШЛЯХИ ФОРМУВАННЯ МЕХАНІЗМУ ІНВЕСТИЦЙННОО ЗАБЕЗПЕЧЕННЯ ВІДТВОРЮВАЛЬНИХ ПРОЦЕСІВ В КОСМІЧНІЙ ГАЛУЗІ
}

\author{
ПУТИ ФОРМИРОВАНИЯ МЕХАНИЗМА ИНВЕСТИЦИОННОГО \\ ОБЕСПЕЧЕНИЯ ПРОЦЕССОВ ВОСПРОИЗВОДСТВА В КОСМИЧЕСКОЙ \\ ОТРАСЛИ
}

\section{WAYS OF FORMING OF THE MECHANISM OF INVESTMENT PROVISION OF REPRODUCTION PROCESSES IN SPACE INDUSTRY}

Стаття присвячена дослідженню сучасних проблем фінансування відтворювальних процесів у космічній галузі України. Проаналізовано сутність відтворювального процесу в космічній галузі та його основні етапи. Визначено зміст інвестицій та охарактеризовано їх функиії у забезпеченні відтворювальних прочесів у космічній галузі. Проаналізовано сучасний стан вітчизняної космічної галузі та ї̈ вплив на конкурентоспроможність національної економіки. Визначено основні завдання інвестиційного забезпечення відтворювальних процесів у космічній галузі. Розкрито зміст заходів, щуо можуть стимулювати розвиток космічної галузі в Україні та забезпечити фінансування розширеного відтворення виробництва в даній галузі економіки. Зокрема, проаналізовано механізм боргового фрінансування космічної галузі за рахунок емісії иільових облігацій внутрішньої державної позики, а також напрямки розвитку державно-приватного партнерства у фінансуванні відтворювальних процесів у космічній галузі. Розглянуто можливість створення венчурних фондів для фінансування інвестицій у інноваційний розвиток космічної галузі України.

Ключові слова: космічна галузь, інвестиції, відтворювальний процес, державні облігації, державно-приватне партнерство, венчурні фонди.

Статья посвящена исследованию современных проблем финансирования проиессов воспроизводства в космической отрасли Украины. Проанализирована сущңность прочесса воспроизводства в космической отрасли и его основные этапы. Определено содержание инвестиций и охарактеризованы их функции в обеспечении процессов воспроизводства в космической отрасли. Проанализировано современное состояние отечественной космической отрасли и ее влияние на конкурентоспособность начиональной экономики. Определены основные задания инвестиционного обеспечения процессов воспроизводства в космической отрасли. Раскрыто содержание мероприятий, которые могут стимулировать развитие космической отрасли в Украине и обеспечить финансирование расширенного воспроизводства в данной отрасли экономики. В частности, проанализирован механизм долгового финансирования космической отрасли за счет эмиссии целевых облигаций внутреннего государственного долга, а также направления развития государственно-частного партнерства в финансировании прочессов воспроизводства в космической отрасли. Рассмотрена возможность создания венчурных фондов для финансирования инвестищий в инновационное развитие космической отрасли Украины. 
Ключевые слова: космическая отрасль, инвестиции, процесс воспроизводства, государственные облигации, государственно-частное партнерство, венчурные фонды.

Article is devoted analysis of modern problems of financing of reproduction processes in space industry of Ukraine. The nature of reproduction process in space industry and its basic stages is analysed. The essence of investments is specified and their functions in provision of reproduction processes in space industry are characterised. The recent state of domestic space industry and its influence on competitiveness of national economy is analysed. The basic tasks of investment provision of processes of reproduction in space industry are specified. The nature of measures which can stimulate development of space industry in Ukraine and provide financing of the expanded reproduction in the given industry of economy are discovered. In particular, the mechanism of debt financing of space industry at the basis of issue of target bonds of an internal public debt, and also a direction of development of state-private partnership in financing of processes of reproduction in space industry are analysed. Possibility of creation of venture capital funds for investment financing in innovative development of space industry of Ukraine is considered.

Keywords: space industry, investments, reproduction process, government bonds, stateprivate partnership, venture funds.

Вступ. В умовах посилення глобалізації та поглиблення євроінтеграційних процесів українські підприємства отримують нові можливості щодо доступу на світові промислові ринки, що у свою чергу обумовлю необхідність підвищення конкурентоспроможності та модернізації економіки України. Адже для того, щоб гідно відповідати на виклики сучасності та ефективно конкурувати із іноземними виробниками на світових ринках, Україна має у повній мірі використовувати ті переваги, якими вона володіє ще 3 радянських часів. Космічна галузь поряд із потужними агропромисловим комплексом та машинобудуванням складає одну із значних конкурентних переваг вітчизняної економіки, яка до нашого часу так і не була повністю реалізована.

На території України розташовані промислові підприємства, науководослідні та інститути інфраструктури, які в комплексні слугують надійним базисом для розвитку космічної індустрії. На жаль, з часу розпаду СРСР обсяг інвестицій у дану галузь національної економіки суттєво скоротився. Усе це знижує господарський потенціал вітчизняної космічної галузі та не дозволяє ій перетворитися на той базис, що може бути використаний для виходу та підтримки конкурентної позиції на глобалізованих промислових ринках.

Відсутність стабільного та достатнього за обсягами фінансування зумовлює застарілість технологічного базису космічної галузі, а відсутність інновацій, які дозволять підвищити ефективність виробництва, підвищити якість продукції та забезпечать розширене відтворення космічної галузі, зумовлюють низьку конкурентоспроможність української космічної продукції на розвинутих глобалізованих ринках. Таким чином, необхідність підвищення ефективності та стимулювання розвитку вітчизняної економіки, а також 
підвищення конкурентоздатності національної космічної галузі та перетворення iï на потужний акселератор економічного зростання обумовлюють необхідність грунтовного дослідження шляхів формування механізму інвестиційного забезпечення відтворювальних процесів у вітчизняній космічній галузі.

Сутність та механізм відтворення космічної галузі, а також значення i закономірності іiі розвитку були висвітлені у вітчизняній науковій економічній літературі. Належне місце в розробці даної наукової тематики займають праці Алексєєва Ю.С., Бендикова М.А., Варналія 3.С., Дульської І.В., Рогача О.І., Сіденка В.Р., Циганова С.А., Черкасової А.В., Шевцова А.І.

Алексєєв Ю.С. дослідив зміни в організації діяльності космічної галузі, здійснені в Україні після розпаду СРСР i шляхи забезпечення конкурентоспроможності вітчизняної космонавтики на світовому ринку. Головним завданням забезпечення конкурентоспроможності вітчизняної космонавтики він визначив продовження реалізації міжнародних проектів [1, c.63]. Дульська I.В. проаналізувала механізм залучення приватного капіталу до розвитку супутникових систем зв'язку в Україні шляхом збільшення комерціоналізації та інвестиційної привабливості діяльності у космічній галузі, а також обгрунтувала необхідність гармонізації вітчизняних космічних програм з аналогічними програмами ЄС [2, с.164]. Черкасова А.В. дослідила вплив іноземних інвестицій на економічний потенціал підприємств космічної галузі України в системі міжнародних космічних досліджень і реалізації конкурентоспроможної продукції на світовому ринку [3, с.428].

Водночас, питання, пов'язані із комплексним аналізом шляхів формування механізму інвестиційного забезпечення відтворювальних процесів у вітчизняній космічній галузі на сучасному етапі розвитку економічних відносин, на наш погляд, вивчені та висвітлені недостатньо.

Постановка завдання. Мета статті полягає у комплексному дослідженні передумов, обгрунтуванні необхідності та визначенні шляхів інвестиційного забезпечення відтворювальних процесів у вітчизняній космічній галузі. Завдання дослідження підпорядковані досягненню поставленої мети і спрямовані на: аналіз сутності відтворювального процесу в космічній галузі та його основних етапів; визначення функцій інвестицій у забезпеченні відтворювальних процесів у космічній галузі; аналіз сучасного стану вітчизняної космічної галузі; дослідження заходів, що можуть стимулювати розвиток космічної галузі в Україні та забезпечити фінансування розширеного відтворення виробництва в даній галузі економіки.

Методологія. Дослідження шляхів інвестиційного забезпечення відтворювальних процесів у вітчизняній космічній галузі передбачає використання загальнонаукових прийомів і методів. 3 використанням методу наукової абстракції та методу діалектики у статті досліджено сутність та 
основні функції інвестицій у забезпеченні відтворювальних процесів у космічній галузі, на основі методів функціонального і системного аналізу проаналізовано завдання інвестування у космічній галузі. 3 використанням методів діалектики, дедукції, поєднання історичного та логічного проаналізовано сучасний вітчизняної космічної галузі, а також проблеми, які супроводжують ії розвиток. На базі методів наукової абстракції та системного аналізу напрямки стимулювання розширеного інвестиційного забезпечення відтворювальних процесів у вітчизняній космічній галузі.

Результати дослідження. 3 моменту освоєння людиною космосу, космічна діяльність держави свідчить про розвиток високотехнологічного виробництва, застосування інновацій та новітніх технологій та сприяє підвищенню міжнародного авторитету на світовій арені. Українська космічна галузь - приклад функціонування науки i високих технологій у сфері суспільного виробництва. В Україні спостерігається поступовий розвиток космічної галузі. За останні роки було реалізовано продукції на суму більше 10 млрд. гривень. Більше $60 \%$ загального обсягу виробництва становить ракетно-космічна продукція. Підприємства ракетно-космічної галузі України в січні-червні 2014 р. збільшили обсяги виробництва продукції на 11,8\% порівняно з аналогічним періодом 2013 року - до 1,54 млрд. грн. Даний успіх вимірюється не лише міжнародним авторитетом, а й рівнем отриманих прибутків. Космічна галузь - $\epsilon$ прибутковим видом підприємницької діяльності. Основними торгівельними партнерами є США, РФ, країни $С С$, Бразилія, Саудівська Аравія. Підприємства ракетно-космічної промисловості виробляють ефективні супутники різного призначення та ракетоносії різних модифікацій, які можуть доправляти на навколоземні орбіти вантажі різноманітного наукового та господарського призначення.

Фінансування космічної галузі - інвестиції в майбутнє держави, ii безпеку, а також розвиток новітніх технологій, підготовка високопрофесійних фахівців. Не зважаючи на загальну тенденцію недофінансування та припинення наукових досліджень в космічній галузі, застарілість основних виробничих фондів та проблематичність практичного застосування інноваційних технологій в галузі, Україна на початку XXI ст. займала четверте місце на ринку виробництва ракет-носіїв, космічних апаратів поступаючись Росії, США та Євросоюзу. Сьогодні частка України оцінюється в 7-9\%, продовжуючи входити в п'ятірку провідних країн космічних послуг та технологій. За результатами роботи української космічної галузі відбулося більше 120 пусків українських ракет-носіїв, виведено на орбіту близько 150 космічних апаратів для 20 країн світу. Важлива роль у створенні економічно рентабельної космічної галузі належить інвестиціям. Щоправда, з метою забезпечення економічної безпеки урядами деяких країн запроваджено відповідне законодавство, що передбачає обмеження чи заборону на 
залучення іноземних інвестицій у космічну галузь. Зокрема така заборона діє у РФ. Водночас, резерви для пошуку джерел інвестицій у космічну галузь можна знайти і всередині країни.

На сучасному етапі перед розширення інвестицій у вітчизняну космічну галузь може забезпечити виконання наступних пріоритетних для економіки України завдань: здійснення дистанційного зондування Землі 3 космосу; удосконалення космічних систем телекомунікації та навігації; провадження космічної діяльності в інтересах національної безпеки та оборони; проведення наукових космічних досліджень; створення космічних комплексів; забезпечення промислово-технологічного розвитку; поглиблення міжнародного співробітництва. Реалізація яких в сучасних соціальноекономічних реаліях України без належного фінансового забезпечення, в тому числі й іноземного, практично неможлива.

На нашу думку, інвестиції у космічну галузь можна визначити як вкладення фінансових ресурсів у виробництво космічної продукції з метою подальшого їх збільшення і отримання економічного ефекту або іншого запланованого результату, такого як підвищення економічної безпеки та покращення макроекономічної ситуації в Україні.

Інвестиції мають здійснюватися на наступних принципах: платність, що передбачає залучення коштів для фінансування інвестицій на платній основі; терміновість, що передбачає встановлення відповідного терміну для використання і окупності залучених фінансових ресурсів; зворотності, що передбачає повернення фінансових ресурсів після завершення терміну їх використання інвесторам.

Головною метою інвестицій є збільшення ринкової вартості активів космічної галузі та підвищення іiі конкурентоспроможності на світових ринках. Серед функцій, які виконують інвестиції у забезпеченні нормальної та ефективної діяльності космічної галузі, слід визначити:

- підвищення конкурентоспроможності космічної галузі;

- розширення виробництва та завоювання нових іноземних ринків збуту продукції;

- протидія моральному і фізичному зносу основних засобів, а також підвищення технічного рівня виробництва в космічній галузі;

- підвищення якості продукції космічної галузі;

- забезпечення працездатного населення новими робочими місцями;

- підвищення рентабельності виробництва;

- мультиплікативний вплив на національний дохід та збільшення ВВП України.

Процес відтворення у космічній галузі, на наш погляд, передбачає постійний рух капіталу (основного, оборотного, інтелектуального) 3 послідовною зміною форм по трьом стадіям виробництва 3 поверненням в 
початкову форму у збільшеному розмірі, що гарантує отримання прибутку від економічної діяльності. Серед стадій відтворювального процесу слід виокремити:

- стадію авансування, на якій відбувається акумулювання залучених у процесі інвестування фінансових ресурсів та їх вкладання у різні форми капіталу;

- стадію виробництва, на якій різні форми капіталу залучаються до процесу виробництва космічної продукції на забезпечують створення доданої вартості;

- стадію реалізації, на якій готова продукція реалізується на ринку і забезпечує надходження на підприємство прибутку. У свою чергу, прибуток перетворюється на джерело фінансування, що використовується для придбання засобів виробництва та початок нового циклу відтворення.

Таким чином, як стає зрозуміло 3 комплексного аналізу функції інвестицій, вони здійснюють визначальний вплив на результативність діяльності підприємств космічної галузі на кожній стадії відтворювального процесу. На першій стадії інвестиції формуються основу для капіталовкладень, на другій стадії інвестиції створюють передумови для підвищення технологічного рівня виробництва, а на третій стадії інвестиції забезпечують отримання конкурентоспроможної продукції, що може зайняти стійке положення на глобалізованих ринках. На жаль, ситуація 3 фінансуванням інвестицій у космічну галузь зажди була і залишається проблемною, що негативно позначається на іії конкурентоспроможності.

5 вересня 2013 р. Законом України було затверджено Загальнодержавну цільову науково-технічну космічну програму України на 2013-2017 роки. Ефективність виконання якої має забезпечити отримання комерційного (прямого) доходу в обсязі орієнтовно 2,5 млрд. гривень; отримання непрямого доходу в обсязі орієнтовно 3,24 млрд. гривень, а також розширити можливості доступу громадян до сучасних інформаційних технологій; збільшити співвідношення між середньою заробітною платою на підприємствах, що підпорядковані Державному космічному агентству України, та в державі до 1,2; збільшити кількість робочих місць до 1250. Не зважаючи на те, що виконання Програми здійснюється в основному за рахунок коштів державного бюджету, планується й залучення коштів з інших джерел, зокрема, на основі державно-приватного партнерства.

Таблиця

Орієнтовний розподіл фінансування за роками (млн. гривень)

\begin{tabular}{|l|l|l|l|l|l|l|}
\hline \multirow{2}{*}{ Джерела фінансування } & \multirow{2}{*}{ Разом } & \multicolumn{5}{|c|}{ За роками } \\
\cline { 3 - 7 } & & 2013 & 2014 & 2015 & 2016 & 2017 \\
\hline Державний бюджет & 1120 & 98,7 & 230,7 & 335,2 & 226,9 & 228,5 \\
\hline
\end{tabular}




\begin{tabular}{|l|l|l|l|l|l|l|}
\hline Інші джерела & 1460 & 389 & 207 & 258 & 295 & 311 \\
\hline Усього & 2580 & 487,7 & 437,7 & 593,2 & 521,9 & 539,5 \\
\hline
\end{tabular}

Джерело: [4]

Залучення значних коштів 3 інших джерел для створення космічної техніки та забезпечення підприємств космічної промисловості стабільними замовленнями, а їх працівників - престижною високооплачуваною роботою передбачає створення сприятливого інвестиційного клімату з боку держави.

Інвестиції $\epsilon$ важливою складовою економічного розвитку економіки країни, а також передумовою для цього ж розвитку. Інвестиційна активність залежить від низки макроекономічних чинників: створення сприятливого інвестиційного клімату через податкове регулювання, ліцензування, антимонопольні заходи; зниження темпів інфляції; зниження ставки відсотка на фінансовому ринку; формування культури інвестування. Інвестиції довготермінові капіталовкладення 3 метою отримання прибутку. Слід пам'ятати, що високий рівень прибутку часто забезпечується за умов високого інвестиційного ризику, з наслідками можливого банкрутства. Безперечно у сучасних ринкових умовах отримання прибутку є одним з важливих завдань інвестиційної діяльності інвестора. Згідно чинного законодавства інвестиції, в тому числі й іноземні, в космічну галузь гарантуються та забезпечуються державою. Інвестиції в комічну галузь - відповідальне економічне рішення, результат яких не завжди співпадає 3 прогнозованим прибутком. Сьогодні інвестування в комічну галузь $є$ не лише черговим способом реалізації геополітичних інтересів високорозвинених країн, а й незаперечним засобом примноження економічного потенціалу для інвестора.

При здійсненні інвестиційної діяльність інвестор має на меті забезпечити максимальну прибутковість при відносній мінімізації підприємницьких ризиків, а також ліквідність інвестицій; при зміні внутрішніх та зовнішніх чинників отримати можливості повторного реінвестування капіталу; зберегти фінансову стабільність та забезпечити платоспроможність інвестора у процесі інвестиційної діяльності - все це в комплексі має сприяти високим темпам економічного розвитку та конкурентоспроможності інвестора.

Інвестування в космічну галузь на загальнодержавному рівні активно сприяє розвитку науково-технічному прогресу, дозволяє створювати нові робочі місця і тим самим опосередковано контролювати рівень безробіття. Крім того інвестиції дозволяють рівномірно розвивати наукоємні галузі народного господарства і тим самим підтримувати стабільний економічний розвиток країни.

Інвестиції дозволяють провести модернізацію устаткування; впливають на збільшення вартості активів підприємства та розвитку виробничих 
потужностей; провести контроль за фізичним та моральним зносом основних виробничих фондів.

Через свою динамічність, інвестиційний процес вимагає комплексу управлінських заходів, які б були спрямовані на формування сприятливого для інвестування середовища. Механізм інвестиційного процесу являє собою систему правових, економічних та організаційних дій, які покликані забезпечити здійснення інвестиційної діяльності. Не менш важливу роль у здійсненні інвестиційної діяльності відіграють управлінські рішення, напрямків яких залежить ефективність та оптимальність капіталовкладення. Визначальними складовими інвестиційного механізму, від яких залежить інвестиційна діяльність, є: нормативно-правова база, інституційна структура ринку (як механізму економічної діяльності), система методів управління інвестиційною діяльністю, система інструментів впливу під конкретну ситуацію інвестиційної діяльності.

Інвестиції в космічну галузь безперечно збільшили б надходження до бюджету. Так як українські підприємства розраховують не стільки на державу, скільки на іноземних замовників. Інвестиції сприяють якісному оновленню підприємства: з'являється доступ до нових технологій та наукових досліджень, 3'являється можливість розширити та підвищити кадровий професійний потенціал, а залучення іноземних інвестицій передбачає посилений контроль за розробкою та виготовленням космічної продукції - все це в цілому не лише підвищу продуктивність діяльності підприємства, а й ефективно впливає на загальну макроекономічну ситуацію в державі.

Українські підприємства, які займаються науковими дослідженнями та виробництвом високотехнологічної космічної продукції використовують всі можливі шляхи пошуку джерел фінансування для свої проектів: бюджетні кошти, залучають приватний капітал, використовують нерозподілений прибуток підприємства, беруть позики як на внутрішньому так i на зовнішньому ринках, укладають міжнародні контракти та ін.

У широкому значенні поняття «механізм» інтерпретує в собі систему складових, процесів певного виду діяльності. У даному випадку механізм інвестиційного забезпечення розглядається як система правових, економічних, організаційних, грошово-кредитних заходів, які здатні впливати на інвестиційну діяльність в космічній галузі. Правова складова даного механізму передбачає розробку та вдосконалення нормативно-правової бази, проведення державних експертиз, ліцензувань інвестиційної діяльності. Прогалини та недосконалість вітчизняного інвестиційного законодавства, не зважаючи на достатньо велику чисельну кількість правових документів (більше 100), є однією з причин, що стоїть на перешкоді залучення інвестицій, в тому числі й іноземних. Для іноземних інвесторів важливо, щоб в державі була розроблена система гарантій захисту інтересів інвесторів у процесі 
здійснення інвестиційної діяльності. Розробка, доопрацювання та відповідно практичне застосування відповідних законів, правил, принципів мають сприяти інвестиційній діяльності, а також забезпечити відповідний контроль за їх виконанням. Важливе місце в механізмі інвестиційного забезпечення належить аспекту економічних відносин, зокрема питанням податкового тиску. 3 одного боку розмір податків може виступати інструментом стимулювання інвестиційної активності платників податку, але, на жаль, Україна не використовує даний інструмент регулювання інвестиційної діяльності у повній мірі. Грошово-кредитна складова механізму має активно залучати фінансові інститути до інвестиційного забезпечення вітчизняних підприємств космічної галузі.

Шляхи формування механізму інвестиційного забезпечення полягають у формуванні привабливого інвестиційного клімату на внутрішньому ринку країни; розробці нормативно-правової бази з питань інноваційної діяльності та інтелектуальної власності; організації комерційної оцінки кожної технології та проведенні інформаційно-рекламних заходів; налагодженні партнерських відносин з міжнародними організаціями та підприємствами в космічній галузі; формуванні та реалізації в майбутньому перспективного сегменту ринку послуг - приватних космічних мандрівок (космічний туризм); створенні рекламних матеріалів та інформаційної бази даних щодо перспектив інвестицій в технології та виробництво комічних товарів та послуг; проведення маркетингових заходів серед представників великого та середнього бізнесу; податкові стимули для потенційних інвесторів.

Для створення сприятливого інвестиційного клімату та забезпечення відтворювальних процесів в космічній галузі державою мають бути забезпечені заходи 3 дерегуляції та забезпечення макроекономічної стабільності: забезпечення помірного рівня інфляції, який не перешкоджатиме економічному розвитку країни; забезпечення збалансованості державних фінансів з реальними можливостями національної економіки; стимулювання здійснення інвестиційних операцій в національній валюті; детінізація економіки; забезпечення фінансової стабільності; зменшення втручання контролюючих органів у господарську діяльність; зниження адміністративних бар'єрів для розвитку підприємництва у космічній галузі.

Серед розглянутих вище шляхів формування механізму інвестиційного забезпечення відтворювальних процесів у вітчизняній космічній галузі, на нашу думку, слід детально зупинитися на фінансуванні відтворювальних процесів у вітчизняній космічній галузі за рахунок цільової емісії державних облігацій та створення спеціалізованих венчурних фондів.

Оскільки важливим джерелом фінансування космічної галузі в Україні залишаються державні кошти, одним 3 перспективних інструментів фінансування підприємств космічній галузі може стати емісія державою 
цільових облігацій внутрішньої позики - емісійних боргових цінних паперів, що розміщуються виключно на внутрішньому фондовому ринку країни i засвідчують зобов'язання країни щодо відшкодування у передбачений умовами строк власникам цих облігацій їх номінальної вартості з виплатою доходу відповідно до умов їх розміщення. Емісія цільових облігацій надасть можливість резидентам країни (фізичним особам і фінансовим інститутам) інвестувати кошти у ліквідні і низько ризиковані фінансові інструменти, отримувати доходи від заощаджень. Водночас, це дозволить залучити на підприємства космічної галузі фінансові ресурси довгострокового характеру для фінансування капіталовкладень.

Сьогодні законодавством України передбачено можливість розміщення наступних видів державних облігацій внутрішньої позики: короткострокових дисконтних облігацій; середньострокових купонних облігацій; довгострокових купонних державних облігацій; довгострокових облігацій зі змінною ставкою доходу, який залежить від індексу споживчих цін; довгострокових облігацій 3 достроковим погашенням; довгострокових амортизаційних облігацій, які передбачають погашення їх номінальної вартості рівними частинами в момент здійснення купонних платежів.

На нашу думку, для фінансування підприємств космічної галузі, де виробничий цикл може бути доволі тривалим, державі краще було б застосовувати довгострокові облігації зі змінною ставкою доходу та довгострокові облігації 3 достроковим погашенням. Поряд із іншим, перевагами використання даних фінансових інструментів $\epsilon$ наявність передбачених державою податкових пільг. Це стимулюватиме інвесторів вкладати кошти в ці фінансові інструменти та фінансувати у такий спосіб вітчизняну космічну галузь.

Іншим перспективним інструментом інвестиційного забезпечення відтворювальних процесів у космічній галузі може стати створення на основі державно-праватного партнерства спеціалізованого венчурного фонду для фінансування інноваційних проектів у космічній галузі. Згідно 3 нормами вітчизняного законодавства венчурний фонд - це недиверсифікований інвестиційний фонд закритого типу, який здійснює виключно приватне розміщення цінних паперів серед юридичних осіб та фізичних осіб і активи якого можуть включати цінні папери, емітовані пов'язаними особами компанії 3 управління активами такого фонду. Оскільки венчурні фонди можуть бути лише закритими, вони не беруть на себе зобов'язань щодо викупу емітованих ними цінних паперів до моменту закриття [5, с.119]. Закриті фонди завжди $\epsilon$ строковими, тобто створюються на визначений строк, після закінчення якого припиняють діяльність, якщо не було прийнято рішення про подовження строку діяльності [6]. Це дозволяє фонду сплачувати податки за результатами своєї діяльності лише після припинення діяльності. Таким чином, інвестиції у 
закритий строковий венчурний фонд є привабливими для інвесторів, оскільки дозволяють «оптимізувати» оподаткування, диверсифікувати ризики, здійснювати належний контроль над об'єктами інвестицій.

Висновки. Наукова новизна одержаних результатів полягає в комплексному дослідженні механізму інвестиційного забезпечення відтворювальних процесів у вітчизняній космічній галузі, що дозволило: вперше проаналізувати перспективи фінансування інвестицій в космічну галузь за рахунок емісії цільових державних облігацій; удосконалити аналіз процесу інвестування в космічній галузі за рахунок визначення сутності відтворювального процесу в космічній галузі та його основних етапів. Крім того, у статті було обгрунтовано можливість та переваги застосування венчурних фондів, побудованих на принципах державно-приватного партнерства, для фінансування інвестицій в космічну галузь.

Проведений аналіз шляхів формування механізму інвестиційного забезпечення відтворювальних процесів у вітчизняній космічній галузі дозволив дослідити сучасний стан національної космічної галузі, виявити тенденції ії розвитку та засвідчив існування важливих проблем, які пов'язані iз повільним провадженням інновацій у космічній галузі внаслідок недостатнього фінансування, що спостерігається протягом останніх років. На підставі проведеного дослідження було зроблено наступні висновки, що стосуються науково-практичних та теоретико-методологічних аспектів цієї важливої проблеми:

1. Протягом останнього десятиліття конкуренція на світових ринках лише зростає, що у поєднанні із євроінтеграційним вектором розвитку України вимагає першочергової модернізації i підвищення конкурентоспроможності вітчизняної економіки. Провідну роль у даному процесі має відігравати національна космічна галузь, що ще 3 радянських часів становить важливу складову вітчизняного промислового сектору та забезпечує зайнятість значної частини працездатного населення.

2. Процес відтворення у космічній галузі передбачає постійний рух капіталу 3 послідовною зміною форм по трьом стадіям виробництва 3 поверненням в першопочатково форму у збільшеному розмірі, що гарантує отримання прибутку від економічної діяльності. При цьому, інвестиції здійснюють визначальний вплив на результативність діяльності підприємств космічної галузі на кожній стадії відтворювального процесу. На першій стадії інвестиції формуються основу для капіталовкладень, на другій стадії інвестиції створюють передумови для підвищення технологічного рівня виробництва, а на третій стадії інвестиції забезпечують отримання конкурентоспроможної продукції, що може зайняти стійке положення на глобалізованих ринках. 
3. Найбільш перспективними шляхами інвестиційного забезпечення розширеного відтворення космічної галузі є фінансування за рахунок цільової емісії державних облігацій та створення спеціалізованих венчурних фондів. Перевагами зазначених механізмів фінансування $\epsilon$ наявність передбачених законодавством України податкових пільг, що стимулюватиме інвесторів вкладати кошти в облігації внутрішньої цільової державної позики та акції венчурних фондів та фінансувати у такий спосіб космічну галузь.

Теоретична значимість результатів дослідження полягає у поглибленні наукового аналізу особливостей інвестиційного забезпечення космічної галузі. Практичне значення одержаних результатів полягає в тому, що вони можуть бути застосовані у процесі розробки державної політики стимулювання розвитку вітчизняної космічної галузі, а також побудови комплексної системи фінансування розширеного відтворення космічної галузі в Україні.

Підсумовуючи дослідження слід зазначити, що актуальність і гострота проблеми забезпечення прискореного розвитку економіки України свідчить про об'єктивну необхідність подальшого дослідження механізмів фінансування відтворювальних процесів у космічній галузі України. Комплексного аналізу потребує стратегія розбудови міжнародного співробітництва у комічній галузі, а також напрямки гармонізації вітчизняного нормативно-правового поля у сфері регулювання інвестицій у космічну галузь із відповідними нормами законодавства СС. Таким чином, актуальність проведення подальших досліджень у даному напрямку $\epsilon$ беззаперечною.

\section{Література:}

1. Алексєєв Ю.С. Космічна діяльність - інноваційний пріоритет України / Ю.С. Алексєєв // Проблеми інноваційно-інвестиційного розвитку. - 2011. - №2. - С.62-65.;

2. Дульська І.В. Державно-публічно-приватне партнерство і розвиток національної супутникової системи зв'язку України / І.В. Дульська // Економічний нобелівський вісник. - 2014. - №1(7). - C.161-170.;

3. Черкасова А.В. Классификация методов оценки инвестиционной привлекательности космической отрасли Украины / А. В. Черкасова // Економіка: проблеми теорії та практики: Збірник наукових праць. - Випуск 231 - Т.II Дніпропетровськ: ДНУ, 2007. - С.423-432;

4. Загальнодержавна цільова науково-технічна космічна програма України на 20132017 роки [Електронний ресурс] - Режим доступу: http://www.nkau.gov.ua/nsau/catalognew.nsf/mainU/69F9BF25A4F7E85 FC22579F700527555. - Назва з екрана;

5. Вірченко В.В. Венчурні фонди та їх роль у відтворенні капіталу / В.В. Вірченко // Фінансово-кредитна діяльність: проблеми теорії та практики. Зб. наук. праць. - Вип. №1(16). - X., 2014. - C.114-123;

6. Закон України «Про інститути спільного інвестування» №5080-VI від 05.07.2012 p. зі змінами $\mathrm{i}$ доповненнями [Електронний ресурс] - Режим доступу: http://zakon2.rada.gov.ua/laws/show/5080-17. - Назва з екрана. 